DOI 10.14746/ssp.2019.4.7

Peter ČAJKA

Faculty of Political Science and International Affairs, Matej Bel University

ORCID: 0000-0003-0568-394X

\title{
Education and science as a soft power tool in Slovakia and V4 countries ${ }^{1}$
}

\begin{abstract}
Already in the Middle Ages, in times of the first universities, education was an important source of knowledge and social status. Nowadays, education, together with its quality and level of teaching, is used as a means of pursuing national interests abroad, as well as influencing local elites, and sometimes even a larger population. High level and good quality of education is one of factors contributing to the relationship between states. The role of education as regards international prestige and the position of individual states has risen in recent years chiefly due to major changes in the global economy and a corresponding shift of values, values which have become important for the modernization of societies. Thus, education has become increasingly important, especially due to the growing significance of knowledge in the globalized world. Education has become an increasingly important factor in international relations and it translates into the soft power of a state.
\end{abstract}

Key words: education, science, universities, patents

\section{Introduction}

\begin{abstract}
high level of quality education is one of the factors that build inter$A$ state power relations. The role of education in international prestige and the position of countries has increased considerably in recent years, mainly because of major changes in the global economy and the corresponding shift in values that have become important in the processes of modernizing the society. In the most developed countries, this economic transformation, sometimes referred to as the fifth "Kondratieff Wave," has brought at least a partial shift from an industrial oil-based production model to a knowledge-based production.
\end{abstract}

1 This research was supported by the project, which has received funding from the VEGA No. 1/0437/19. 
In modern times, education is used as a means of promoting national interests abroad, as well as having an impact on local elites and sometimes even the wider population. In the case of higher education, soft power is also exercised through its impact on intellectual and scientific life and the spread of ideas around the world.

Educated people have a higher degree of trust among themselves. Higher education leads not only to an economically successful society, but also to a healthier democracy, based on a sense of universal trust, as well as on the possibility of influencing what is happening in their country. Education is also an effective policy tool. In a democracy-based society, educated people are involved in decision-making and are politically active. Education therefore has a positive relationship to a healthy democracy.

\section{The position of education and research in V4 countries}

The Slovak Republic is a small and relatively young democratic state. Since its independence, the young republic has had to go through a fundamental transformation process - the communist regime has been replaced with democracy and centrally planned economy has turned into a market economy. At the international level, the country has seen three landmark events. The turning point was the year of 2004, when Slovakia's accession to the European Union was accompanied by its accession to the North Atlantic Treaty Organization. In addition, in 2009, the Slovak Republic, unlike the Czech Republic, Poland and Hungary, switched to the common European currency - Euro. The currency is now used by nineteen out of twenty-eight Member States.

The Slovak Republic has several resources that can potentially increase its soft power. In terms of its territory and population (5.4 million), a relatively small country in the EGPI ranking (2018) ranks $63^{\text {rd }}$ in terms of its soft power. (see Table 1) Since joining the European Union, Slovakia has been worse off by nine ranks, ranking $54^{\text {th }}$ in 2005 . In 2018 , tourism $(31.4 \%-43$ place $)$, sport $(23.8 \%-45$ place $)$ and information $(21.6 \%-63$ place $)$ contributed most to the soft impact. Surprisingly, the least soft power contribution comes from culture $(1.4 \%$ -64 place). 


\begin{tabular}{|c|c|c|c|c|c|c|c|c|c|}
\hline & $\stackrel{\infty}{\stackrel{\text { ㄱ }}{2}}$ & $\begin{array}{l}\hat{\sigma} \\
a \\
a \\
\hat{a}\end{array}$ & 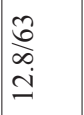 & $\begin{array}{l}\stackrel{Y}{+} \\
\underset{J}{\infty} \\
\stackrel{+}{+}\end{array}$ & $\begin{array}{l}\vec{y} \\
0 \\
\dot{0} \\
m\end{array}$ & 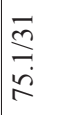 & 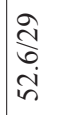 & 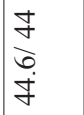 & 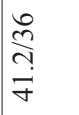 \\
\hline \multirow{11}{*}{ 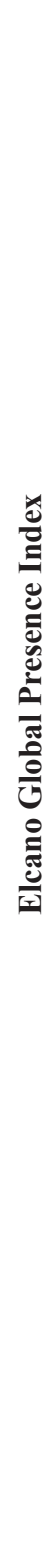 } & $\frac{\pi}{\partial}$ & $\begin{array}{l}\mathfrak{\sigma} \\
\tilde{m} \\
a \\
-\end{array}$ & $\begin{array}{l}30 \\
0 \\
\dot{2}\end{array}$ & $\begin{array}{l}\frac{n}{m} \\
\tilde{n} \\
\tilde{y}\end{array}$ & $\begin{array}{l}\infty \\
\substack{n \\
\partial \\
\infty \\
m}\end{array}$ & $\frac{N}{\pi}$ & $\begin{array}{l}\text { Ǹ } \\
\text { à } \\
\dot{⿰}\end{array}$ & $\begin{array}{l}\text { J } \\
\text { ơ } \\
\text { r }\end{array}$ & $\begin{array}{l}\stackrel{+}{N} \\
\stackrel{n}{\sim} \\
\stackrel{f}{1}\end{array}$ \\
\hline & 룰 & $\begin{array}{l}\tilde{\sigma} \\
\infty \\
\infty \\
\infty \\
-1\end{array}$ & $\begin{array}{l}\stackrel{3}{\stackrel{3}{c}} \\
\end{array}$ & $\begin{array}{l}\hat{n} \\
\text { ò } \\
\dot{0}\end{array}$ & 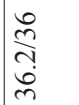 & $\begin{array}{l}\frac{1}{2} \\
\frac{\alpha}{\infty} \\
0\end{array}$ & 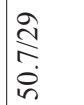 & $\begin{array}{l}\stackrel{g}{g} \\
\text { 荈 }\end{array}$ & $\begin{array}{l}\hat{m} \\
\hat{\sigma} \\
\dot{q}\end{array}$ \\
\hline & 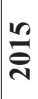 & $\begin{array}{l}\hat{0} \\
\overrightarrow{+} \\
\stackrel{+}{1}\end{array}$ & $\begin{array}{l}\hat{\sigma} \\
\stackrel{n}{=}\end{array}$ & 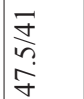 & $\frac{\dot{m}}{\text { à }}$ & 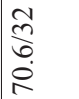 & $\begin{array}{l}\stackrel{\Im}{\alpha} \\
\infty \\
\stackrel{q}{q}\end{array}$ & $\begin{array}{l}\frac{y}{y} \\
\tilde{n} \\
\dddot{y} \\
y\end{array}$ & $\begin{array}{l}\stackrel{\curvearrowright}{\sigma} \\
\stackrel{\sim}{\sigma}\end{array}$ \\
\hline & 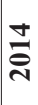 & $\begin{array}{l}\text { Uல } \\
0 \\
0 \\
0\end{array}$ & $\begin{array}{l}\text { to } \\
a \\
0 \\
0\end{array}$ & $\begin{array}{l}\vec{y} \\
\underset{J}{J} \\
\dot{+}\end{array}$ & 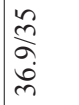 & 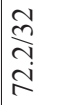 & $\begin{array}{l}\stackrel{\infty}{\sim} \\
\sim \\
\sim \\
\dot{\sigma}\end{array}$ & 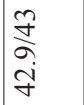 & $\begin{array}{l}0 \\
⿱ n \\
\partial \\
\ddot{n} \\
\ddot{n}\end{array}$ \\
\hline & $\stackrel{m}{\stackrel{\text { ల }}{2}}$ & $\begin{array}{l}\hat{\sigma} \\
\stackrel{2}{2}\end{array}$ & $\begin{array}{l}\stackrel{8}{\stackrel{0}{0}} \\
= \\
=\end{array}$ & 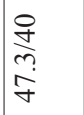 & $\begin{array}{l}\underset{m}{\sim} \\
\text { } \\
\infty \\
m\end{array}$ & 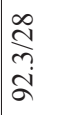 & $\begin{array}{l}\hat{N} \\
\vdots \\
\alpha \\
\dot{\sigma}\end{array}$ & 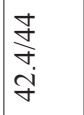 & $\begin{array}{l}\infty \\
\stackrel{\infty}{r} \\
\dot{m} \\
\dot{m}\end{array}$ \\
\hline & $\stackrel{N}{\stackrel{\sim}{\mathcal{N}}}$ & $\begin{array}{l}0 \\
8 \\
0 \\
0 \\
0\end{array}$ & $\begin{array}{l}\infty \\
\stackrel{n}{\curvearrowleft} \\
=\end{array}$ & $\begin{array}{l}\stackrel{\rho}{+} \\
\infty \\
\infty \\
\infty \\
+\end{array}$ & $\begin{array}{l}\hat{m} \\
\infty \\
\dot{m}\end{array}$ & $\begin{array}{l}\vec{r} \\
\stackrel{r}{r}\end{array}$ & \begin{tabular}{l}
$\hat{N}$ \\
\multirow{\partial}{*}{} \\
$\stackrel{+}{y}$
\end{tabular} & $\begin{array}{l}\stackrel{0}{+} \\
\text { iv } \\
\text { r }\end{array}$ & $\begin{array}{l}n \\
n \\
n \\
n \\
n\end{array}$ \\
\hline & $\overline{\bar{\sigma}}$ & ڤ્ & $\begin{array}{l}\stackrel{0}{n} \\
n \\
=\end{array}$ & $\begin{array}{l}\vec{y} \\
\text { フे } \\
\dot{y}\end{array}$ & 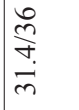 & $\begin{array}{l}0 \\
n \\
n \\
g \\
0\end{array}$ & $\begin{array}{l}\stackrel{\text { ปे }}{\partial} \\
\stackrel{+}{+}\end{array}$ & $\begin{array}{l}n \\
\stackrel{1}{\infty} \\
\infty \\
\infty \\
m\end{array}$ & 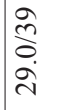 \\
\hline & 응 & $\begin{array}{l}\hat{n} \\
\partial \\
\stackrel{\sigma}{2}\end{array}$ & $\begin{array}{l}\stackrel{\infty}{n} \\
a \\
\stackrel{0}{0}\end{array}$ & $\begin{array}{l}\stackrel{P}{9} \\
\text { m } \\
\dot{f}\end{array}$ & $\begin{array}{l}\infty \\
\text { ñ } \\
\text { ते }\end{array}$ & 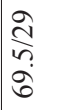 & $\begin{array}{l}0 \\
m \\
m \\
\infty \\
m\end{array}$ & $\begin{array}{l}n \\
\dot{y} \\
m \\
\infty \\
m\end{array}$ & \begin{tabular}{l}
$\stackrel{a}{m}$ \\
\multirow{2}{v}{}
\end{tabular} \\
\hline & ్ֻ̊ㅀ & $\begin{array}{l}\bar{\sigma} \\
\tilde{n} \\
\underline{6}\end{array}$ & \begin{tabular}{l}
$\stackrel{+}{n}$ \\
\multirow{\sigma}{\sigma}{} \\
$\sigma$
\end{tabular} & $\begin{array}{l}\text { J } \\
\infty \\
\dot{m}\end{array}$ & $\frac{\stackrel{ }{+}}{\stackrel{i}{N}}$ & $\frac{n}{\frac{n}{a}}$ & $\begin{array}{l}\infty \\
\stackrel{\infty}{n} \\
n \\
0 \\
n\end{array}$ & 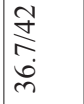 & $\begin{array}{l}m \\
\stackrel{m}{r} \\
\dot{\infty} \\
\sim\end{array}$ \\
\hline & & 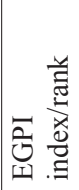 & 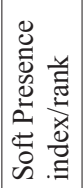 & 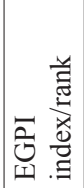 & 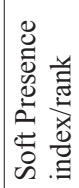 & 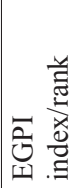 & 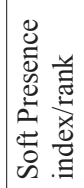 & 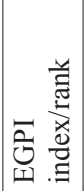 & 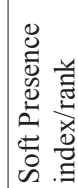 \\
\hline & $\underset{>}{\nabla}$ & $\begin{array}{l}\frac{\pi}{\frac{\pi}{2}} \\
\frac{\pi}{\pi} \\
\frac{0}{n}\end{array}$ & & 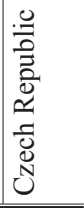 & & 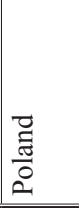 & & 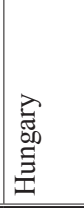 & \\
\hline
\end{tabular}




\section{Order of the V4 States within the EGPI}

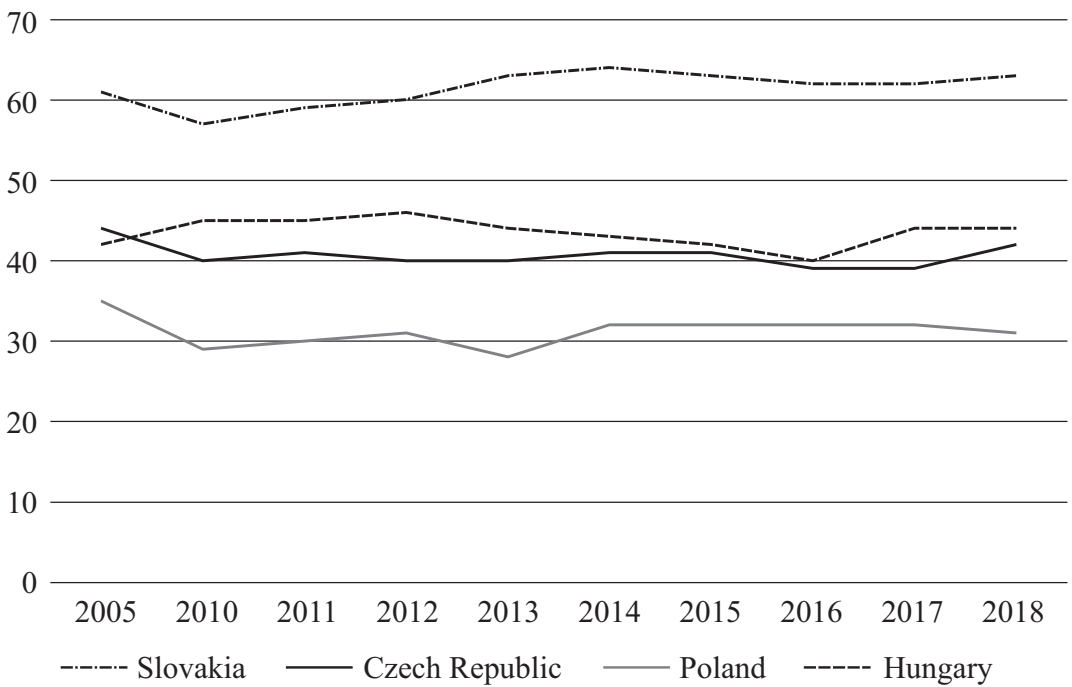

Source: Own processing by Elcano Global Presence Index.

The positioning of individual countries in the EGPI chart shows that the level achieved in the V4 countries is very different in terms of both the overall position of the countries in the global EGPI indicator and in the education indicator. The above indicators show that the position of the Slovak Republic is the worst of the V4 countries. During the period 2010-2018, the Slovak Republic recorded a long-term decline in the ranking, while at the same time the country had the largest drop by 6 places in the ranking. The other countries under review recorded a fairly balanced course in their placement with minimal differences. At the same time, the Czech Republic and Hungary recorded a significant fall, respectively by 3 and 4 places.

The quality of higher education is also reflected in QS World University Rankings (QS WUR). The Slovak Republic is in the first thousand for the period 2012-2020 by three universities - Comenius University in Bratislava, Slovak University of Technology in position \# 751-800 and Technical University of Košice in position \# 801-1000. (QS WUR, 2019) However, none of the Slovak universities is represented in this ranking for the whole period. The Comenius University appeared for the first time in the ranking in 2016, when it also achieved the best rank- 
ing of \# 651-700. In 2017, the Comenius University recorded a decline in ranking. The other two Slovak universities found themselves in QS WUR only in 2019.

Compared to other V4 countries, Slovak universities have the worst position in the ranking in terms of the total number of universities represented. In the case of the Czech Republic, four Czech universities ranked QS WUR, 16 in the case of Polish universities and 6 in the case of Hungarian universities. At the same time, we must state that only in the case of Slovak universities, no university is represented in the ranking in the entire monitored period of 2012-2020. All four Czech universities are represented, six in the case of Poland and four in the case of Hungary. The best places in ratings among the V4 countries reached in 2020 is occupied by the Charles University (\# = 291), Jagiellonian University (\# = 338), University of Szeged (\# 501-510) and finally the Comenius University (\# 751-800) (see Table 2).

In the area of education as a soft power factor within the EGPI, the situation in the V4 countries compared to Slovakia is significantly different (see Table 3). As in the case of the overall poor performance of Slovakia (63 place) within the EGPI, we also achieve the sovereign least favourable position (56 place) in education. The development in the last three years has been striking, Slovakia achieved the largest drop by 7 places, while the course was relatively balanced. A similar situation was recorded by the Czech Republic. Since 2011, the country has been the only one that had been experiencing a long-term decline by 8 places, which culminated at $30^{\text {th }}$ place in 2017 . The Czech Republic recorded the most significant overall drop in the monitored indicators among all V4 countries in the period under review. Slovakia and the Czech Republic, as the only two countries among the V4 countries, recorded a decline in education. Since 2016, Hungary, contrary to Slovakia, has strengthened its position in the ranking by 4 places, to the current third position among the V4 countries and a total of 34 places. Poland has seen the most positive development in education. Poland has been steadily strengthening its overall position since 2010 (34th place) and is currently ranking best at the 20th place among the V4 countries. At the same time, we can state that in the monitored period 2010-2018, in 2017 the greatest difference in the table position was reached among all V4 countries in the area of education. Poland is best placed in 20th place and on the other hand it is 56th place in Slovakia. 


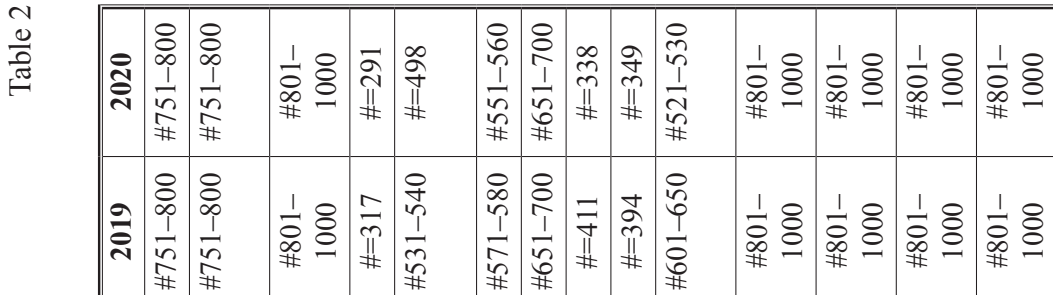

\begin{tabular}{|c|c|c|c|c|c|c|c|c|c|c|c|c|c|c|}
\hline 疍 & 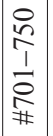 & 1 & 1 & $\frac{\Delta}{\#}$ & 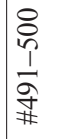 & 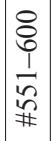 & $\begin{array}{l}0 \\
0 \\
0 \\
1 \\
0 \\
0 \\
\# \\
\#\end{array}$ & 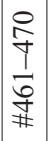 & 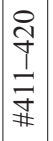 & $\begin{array}{l}0 \\
0 \\
0 \\
1 \\
0 \\
0 \\
\#\end{array}$ & $\begin{array}{l}1 \\
\stackrel{\infty}{\circ} \\
\# \\
\#\end{array}$ & $\begin{array}{l}1 \\
\stackrel{1}{8} \\
\infty \\
\#\end{array}$ & $\begin{array}{l}\frac{1}{8} \\
\infty \\
\#\end{array}$ & $\begin{array}{l}1 \\
\stackrel{8}{8} \\
\# \\
\#\end{array}$ \\
\hline 흥 & $\begin{array}{l}8 \\
\stackrel{2}{1} \\
\frac{1}{2} \\
\vdots \\
\#\end{array}$ & 1 & 1 & 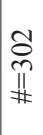 & $\begin{array}{l}0 \\
n \\
i \\
1 \\
\stackrel{0}{0} \\
\dddot{n} \\
\#\end{array}$ & 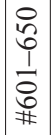 & \begin{tabular}{l}
8 \\
$\stackrel{2}{1}$ \\
$\frac{1}{2}$ \\
\hdashline \\
$\#$
\end{tabular} & 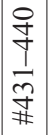 & $\begin{array}{l}0 \\
0 \\
\mathbb{2} \\
\# \\
\#\end{array}$ & 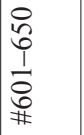 & $\underset{+}{+}$ & $\underset{+}{+}$ & $\underset{7}{+}$ & 1 \\
\hline 륭 & $\begin{array}{l}8 \\
\stackrel{8}{1} \\
\frac{1}{2} \\
0 \\
\#\end{array}$ & 1 & 1 & $\underset{\mathbb{N}}{\stackrel{2}{N}}$ & \begin{tabular}{l}
8 \\
8 \\
+ \\
\multirow{n}{*}{} \\
$¥$ \\
$\#$
\end{tabular} & $\begin{array}{l}8 \\
8 \\
1 \\
\vdots \\
n \\
¥\end{array}$ & 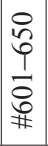 & $\begin{array}{l}\stackrel{̊}{\mathcal{Y}} \\
\underset{7}{\mp} \\
\underset{\#}{\ddagger}\end{array}$ & $\begin{array}{l}\exists \\
\text { J } \\
\#\end{array}$ & 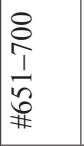 & $\underset{\#}{+}$ & $\underset{+}{+}$ & $\stackrel{+}{\frac{1}{2}}$ & 1 \\
\hline 啇 & 1 & 1 & 1 & $\underset{\mathbb{Z}}{\stackrel{\Xi}{\sharp}}$ & 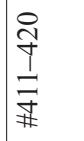 & \begin{tabular}{c}
8 \\
0 \\
1 \\
\hdashline$n$ \\
$¥$ \\
$¥$
\end{tabular} & $\begin{array}{l}8 \\
8 \\
\frac{1}{2} \\
\\
\#\end{array}$ & $\overrightarrow{\tilde{n}}$ & $\begin{array}{l}n \\
\tilde{n} \\
\#\end{array}$ & 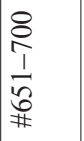 & $\underset{\#}{+}$ & $\underset{+}{+}$ & $\underset{\#}{+}$ & 1 \\
\hline 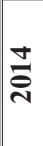 & 1 & 1 & 1 & $\stackrel{\widetilde{N}}{\#}$ & 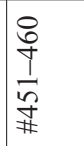 & $\mid \begin{array}{c}8 \\
0 \\
1 \\
\\
n \\
¥\end{array}$ & $\begin{array}{l}8 \\
\stackrel{2}{1} \\
\frac{1}{2} \\
\vdots 0 \\
\#\end{array}$ & $\begin{array}{l}0 \\
2 \\
\pi \\
\#\end{array}$ & $\begin{array}{l}\infty \\
\tilde{n} \\
\pi \\
\#\end{array}$ & \begin{tabular}{l}
0 \\
\multirow{2}{0}{} \\
1 \\
0 \\
0 \\
$\#$
\end{tabular} & $\underset{+}{+}$ & $\underset{\#}{+}$ & $\underset{\#}{+}$ & 1 \\
\hline ত্ণ & I & 1 & 1 & $\begin{array}{l}\infty \\
\stackrel{\infty}{N} \\
\#\end{array}$ & \begin{tabular}{l}
0 \\
$n$ \\
$i n$ \\
1 \\
0 \\
\hdashline \\
$\#$
\end{tabular} & 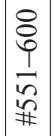 & $\begin{array}{l} \pm \\
\stackrel{+}{\delta} \\
\#\end{array}$ & 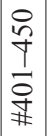 & $\begin{array}{l}\infty \\
2 \\
\tilde{N} \\
\#\end{array}$ & $\begin{array}{l} \pm \\
0 \\
0 \\
\#\end{array}$ & $\begin{array}{l}+ \\
0 \\
8 \\
\text { \# }\end{array}$ & $\underset{\#}{+}$ & $\underset{7}{+}$ & I \\
\hline 离 & 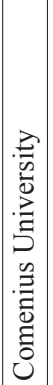 & 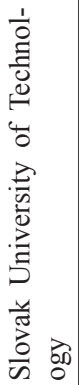 & 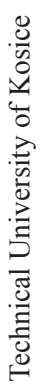 & 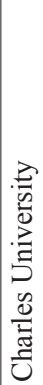 & 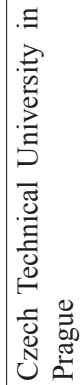 & 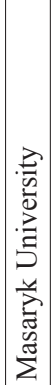 & 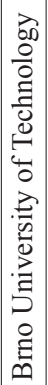 & 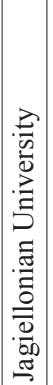 & 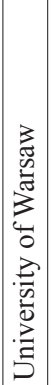 & 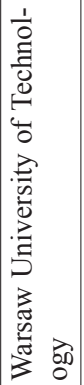 & 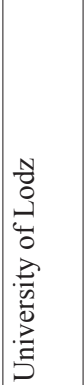 & 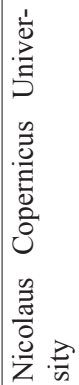 & 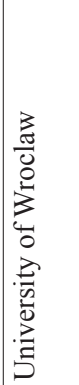 & 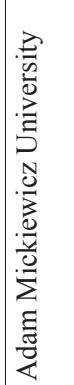 \\
\hline & $\frac{v}{\omega}$ & & & & & & & 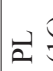 & & & & & & \\
\hline
\end{tabular}




\begin{tabular}{|c|c|c|c|c|c|c|c|c|c|c|c|c|c|c|}
\hline $\begin{array}{l}1 \\
\stackrel{\infty}{\infty} \\
\# \\
\#\end{array}$ & $\begin{array}{ll}1 & 8 \\
\infty & 8 \\
\infty & 0 \\
\# & 0\end{array}$ & $\begin{array}{l}1 \\
\infty \\
\infty \\
\$ \\
\#\end{array}$ & 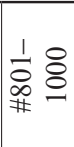 & $\begin{array}{ll}1 & 8 \\
\infty & 8 \\
\infty & 0 \\
\#\end{array}$ & $\begin{array}{ll}1 & 8 \\
8 & 8 \\
\infty & 0\end{array}$ & $\begin{array}{ll}1 & 8 \\
\circ & 8 \\
\infty & 0 \\
\# & -1\end{array}$ & $\begin{array}{ll}1 & 8 \\
\infty & 8 \\
\# & 0\end{array}$ & $\mid \begin{array}{cc}1 & 8 \\
8 & 8 \\
\infty & 8 \\
\# & \end{array}$ & $\begin{array}{l}0 \\
\frac{1}{n} \\
1 \\
0 \\
0 \\
\#\end{array}$ & $\begin{array}{l}0 \\
0 \\
0 \\
1 \\
8 \\
0 \\
\#\end{array}$ & $\begin{array}{l}8 \\
\stackrel{0}{1} \\
\frac{1}{0} \\
\# \\
\#\end{array}$ & $\frac{1}{8} 8$ & 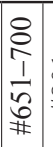 & $\begin{array}{ll}1 & 8 \\
\triangleright & 8 \\
\# & 0\end{array}$ \\
\hline $\begin{array}{l}1 \\
\frac{\infty}{\infty} \\
\#\end{array}$ & $\begin{array}{ll}1 & 8 \\
\circ & 8 \\
\infty & 0 \\
\# & 0\end{array}$ & $\begin{array}{ll}1 & 8 \\
\infty & 8 \\
\infty & 0\end{array}$ & $\begin{array}{l}1 \\
\stackrel{1}{\infty} \\
\infty \\
\$ \\
\#\end{array}$ & $\begin{array}{cc}1 & 8 \\
\infty & 8 \\
\infty & 0 \\
\# & 0\end{array}$ & $\begin{array}{ll}1 & 8 \\
\infty & 8 \\
\# & 0\end{array}$ & $\left|\begin{array}{cc}1 & 8 \\
0 & 8 \\
\infty & 0 \\
\# & 0\end{array}\right|$ & I & 1 & 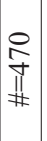 & $\begin{array}{l}8 \\
8 \\
1 \\
1 \\
8 \\
0 \\
\#\end{array}$ & 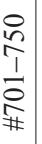 & $\frac{1}{\circ} 8$ & $\begin{array}{l}\stackrel{0}{n} \\
i \\
\frac{1}{2} \\
\frac{1}{\#}\end{array}$ & $\underset{1}{1} 8$ \\
\hline$\frac{1}{\circ} 8$ & $\begin{array}{ll}1 & 8 \\
\circ & 8 \\
\# & 0\end{array}$ & I & 1 & 1 & I & 1 & I & 1 & $\begin{array}{l}0 \\
n \\
1 \\
1 \\
0 \\
n \\
\#\end{array}$ & $\begin{array}{l}8 \\
\frac{1}{1} \\
\frac{n}{0} \\
\#\end{array}$ & $\begin{array}{l}8 \\
8 \\
1 \\
\frac{1}{6} \\
\# \\
\#\end{array}$ & $\frac{1}{1} 8$ & $\begin{array}{l}8 \\
8 \\
\infty \\
1 \\
n \\
\# \\
\#\end{array}$ & $\begin{array}{l}8 \\
\infty \\
1 \\
\frac{n}{n} \\
\#\end{array}$ \\
\hline 1 & 1 & I & 1 & 1 & 1 & 1 & 1 & I & $\begin{array}{l}\circ \\
n \\
i \\
i \\
0 \\
\# \\
\#\end{array}$ & $\begin{array}{l}8 \\
\frac{1}{1} \\
\frac{n}{0} \\
\#\end{array}$ & $\begin{array}{l}0 \\
0 \\
0 \\
1 \\
8 \\
8 \\
\# \\
*\end{array}$ & $\frac{+}{2}$ & $\underset{\#}{+}$ & $\underset{\#}{\stackrel{+}{*}}$ \\
\hline 1 & 1 & I & 1 & 1 & I & I & 1 & 1 & $\begin{array}{l}8 \\
n \\
i \\
1 \\
0 \\
\# \\
\#\end{array}$ & $\begin{array}{l}8 \\
8 \\
0 \\
1 \\
8 \\
0 \\
\#\end{array}$ & $\begin{array}{l}0 \\
2 \\
0 \\
1 \\
0 \\
0 \\
\# \\
\#\end{array}$ & $\frac{+}{\frac{+}{0}}$ & 1 & 1 \\
\hline 1 & 1 & 1 & 1 & 1 & I & 1 & 1 & 1 & $\mid \begin{array}{l}8 \\
0 \\
1 \\
n \\
¥ \\
¥\end{array}$ & 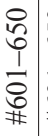 & $\begin{array}{l}0 \\
0 \\
0 \\
1 \\
8 \\
0 \\
\#\end{array}$ & $\underset{\#}{ \pm}$ & I & 1 \\
\hline 1 & 1 & I & 1 & 1 & 1 & 1 & 1 & 1 & 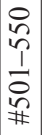 & $\begin{array}{l}0 \\
0 \\
1 \\
1 \\
8 \\
\vdots\end{array}$ & 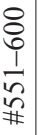 & 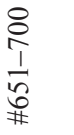 & I & 1 \\
\hline 1 & 1 & I & 1 & 1 & 1 & 1 & I & 1 & $\mid \begin{array}{l}0 \\
n \\
i \\
i \\
0 \\
\# \\
\#\end{array}$ & $\begin{array}{l} \pm \\
\pm \\
8 \\
\$ \\
\#\end{array}$ & $\begin{array}{l}8 \\
0 \\
0 \\
1 \\
n \\
n \\
\#\end{array}$ & $\begin{array}{l}8 \\
0 \\
1 \\
1 \\
n \\
\vdots \\
\#\end{array}$ & I & 1 \\
\hline 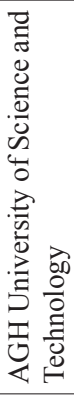 & 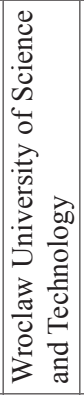 & 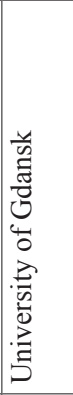 & 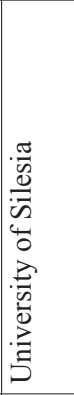 & 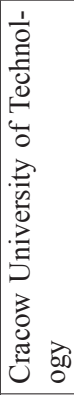 & 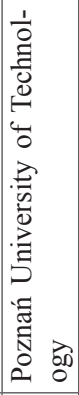 & 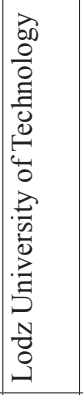 & 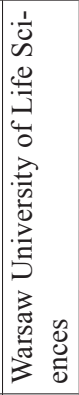 & 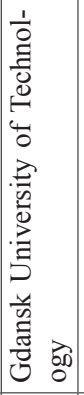 & 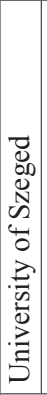 & 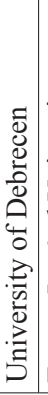 & 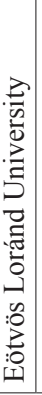 & 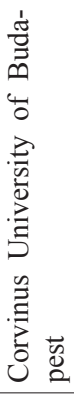 & 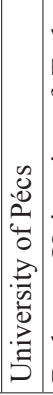 & 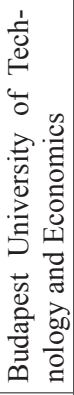 \\
\hline & & & & & & & & & \multicolumn{6}{|c|}{$\stackrel{\ominus}{\ominus}$} \\
\hline
\end{tabular}




\section{Elcano Global Presence Index - Education}

Table 3

\begin{tabular}{||c|l|c|c|c|c|c|c|c|c|c|c|}
\hline \hline V4 & & $\mathbf{2 0 0 5}$ & $\mathbf{2 0 1 0}$ & $\mathbf{2 0 1 1}$ & $\mathbf{2 0 1 2}$ & $\mathbf{2 0 1 3}$ & $\mathbf{2 0 1 4}$ & $\mathbf{2 0 1 5}$ & $\mathbf{2 0 1 6}$ & $\mathbf{2 0 1 7}$ & $\mathbf{2 0 1 8}$ \\
\hline Slovakia & Education & $2.3 /$ & $8.4 /$ & $10.5 /$ & $11.4 /$ & $11.7 /$ & $13.0 /$ & $14.0 /$ & $13.6 /$ & $12.4 /$ & $12.3 /$ \\
& index/rank & 62 & 53 & 50 & 50 & 50 & 49 & 49 & 49 & 56 & 56 \\
\hline Czech & Education & $25.9 /$ & $40.9 /$ & $46.2 /$ & $49.6 /$ & $50.9 /$ & $51.2 /$ & $51.9 /$ & $52.0 /$ & $52.8 /$ & $52.2 /$ \\
Republic & index/rank & 23 & 24 & 22 & 23 & 25 & 26 & 26 & 28 & 30 & 29 \\
\hline Poland & Education & $14.3 /$ & $22.7 /$ & $24.2 /$ & $27.0 /$ & $30.3 /$ & $35.4 /$ & $43.7 /$ & $54.8 /$ & $67.5 /$ & $66.7 /$ \\
& index/rank & 38 & 34 & 34 & 34 & 32 & 30 & 29 & 25 & 20 & 20 \\
\hline Hungary & Education & $19.0 /$ & $19.4 /$ & $20.6 /$ & $21.5 /$ & $22.6 /$ & $26.4 /$ & $29.3 /$ & $27.1 /$ & $32.2 /$ & $31.9 /$ \\
38 & 37 & 38 & 38 & 38 & 38 \\
& index/rank & 31 & 37 & 37 & 38 & 39 & 38 & 34 \\
\hline
\end{tabular}

Source: Own processing by Elcano Global Presence Index.

\section{Order of the V4 States within the EGPI - Education}
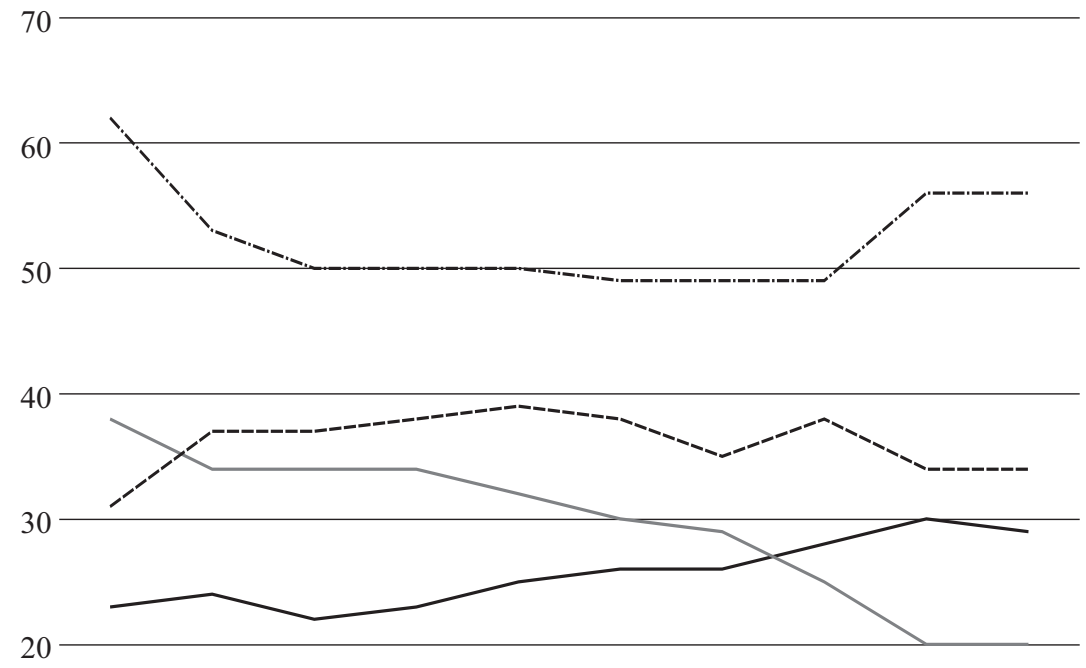

10

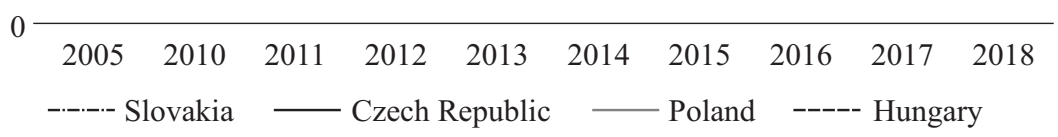

Source: Own processing by Elcano Global Presence Index. 


\section{Science}

In the field of science, as a soft power factor within the EGPI, the situation in Slovakia is similar to the level of education compared to the V4 countries. Regarding this indicator, Slovakia ranked lowest among the V4 countries and the overall position of Slovakia within the EGPI reached $49^{\text {th }}$ position. (see Table 4) Similarly, as in the case of education, also in the case of science, Slovakia has experienced a significant negative trend in the last three years, with a fall of up to 5 places. The past course from 2010 to 2016 was relatively balanced. A similar situation of the table slump was also recorded in the Czech Republic and Poland, which was not as significant as in the case of Slovakia. Interesting is the common phenomenon for all three countries, with the best ranking in 2016. Another example is the development in Hungary, which since 2010 has been constantly negative development, respectively. drop in placement in science. However, this is in contrast to R\&D spending of $1.35 \%$ of GDP (see Table 5), which is the second highest overall in the V4 countries. In the period under review, the Czech Republic and Poland have been constantly developing in the support of science as a soft power factor. Poland is in the top 20 position, despite the fact that the Czech Republic has the highest R\&D expenditure in $\%$ of GDP in the long term at $1.79 \%$, while Poland is in third place with $1.03 \%$ of GDP. Despite this disproportion, unlike Hungary and Slovakia, in Poland, science has a priority position in soft power.

Table 4

Elcano Global Presence Index - Science

\begin{tabular}{||l|l|c|c|c|c|c|c|c|c|c|c||}
\hline \hline V4 & & $\mathbf{2 0 0 5}$ & $\mathbf{2 0 1 0}$ & $\mathbf{2 0 1 1}$ & $\mathbf{2 0 1 2}$ & $\mathbf{2 0 1 3}$ & $\mathbf{2 0 1 4}$ & $\mathbf{2 0 1 5}$ & $\mathbf{2 0 1 6}$ & $\mathbf{2 0 1 7}$ & $\mathbf{2 0 1 8}$ \\
\hline $\begin{array}{l}\text { Slova- } \\
\text { kia }\end{array}$ & $\begin{array}{l}\text { Science } \\
\text { index/rank }\end{array}$ & $\begin{array}{c}10.0 / \\
64\end{array}$ & $\begin{array}{c}17.3 / \\
45\end{array}$ & $\begin{array}{c}17.1 / \\
45\end{array}$ & $\begin{array}{c}16.1 / \\
48\end{array}$ & $\begin{array}{c}18.4 / \\
46\end{array}$ & $\begin{array}{c}19.2 / \\
46\end{array}$ & $\begin{array}{c}23.8 / \\
45\end{array}$ & $\begin{array}{c}23.6 / \\
44\end{array}$ & $\begin{array}{c}24.5 / \\
45\end{array}$ & $\begin{array}{c}15.6 / \\
49\end{array}$ \\
\hline $\begin{array}{l}\text { Czech } \\
\text { Repu- } \\
\text { blic }\end{array}$ & $\begin{array}{l}\text { Science } \\
\text { index/rank }\end{array}$ & $\begin{array}{c}31.4 / \\
29\end{array}$ & $\begin{array}{c}58.7 / \\
25\end{array}$ & $\begin{array}{c}58.0 / \\
25\end{array}$ & $\begin{array}{c}57.7 / \\
26\end{array}$ & $\begin{array}{c}59.3 / \\
26\end{array}$ & $\begin{array}{c}61.6 / \\
26\end{array}$ & $\begin{array}{c}70.8 / \\
25\end{array}$ & $\begin{array}{c}74.3 / \\
24\end{array}$ & $\begin{array}{c}72.3 / \\
25\end{array}$ & $\begin{array}{c}53.1 / \\
28\end{array}$ \\
\hline $\begin{array}{l}\text { Poland } \\
\text { Science } \\
\text { index/rank }\end{array}$ & $68.1 /$ & $97.1 /$ & $96.0 /$ & $96.5 /$ & $104.2 /$ & $108.4 /$ & $117.1 /$ & $124.8 /$ & $132.2 /$ & $103.4 /$ \\
19 & 19 & 20 & 19 & 19 & 19 & 18 & 18 & 20 \\
\hline $\begin{array}{l}\text { Hun- } \\
\text { gary }\end{array}$ & $\begin{array}{l}\text { Science } \\
\text { index/rank }\end{array}$ & $\begin{array}{c}25.4 / \\
32\end{array}$ & $\begin{array}{c}28.9 / \\
38\end{array}$ & $\begin{array}{c}28.5 / \\
38\end{array}$ & $\begin{array}{c}28.8 / \\
38\end{array}$ & $\begin{array}{c}30.4 / \\
41\end{array}$ & $\begin{array}{c}31.6 / \\
41\end{array}$ & $\begin{array}{c}34.1 / \\
41\end{array}$ & $\begin{array}{c}33.0 / \\
43\end{array}$ & $\begin{array}{c}32.7 / \\
43\end{array}$ & $\begin{array}{c}27.4 / \\
43\end{array}$ \\
\hline
\end{tabular}

Source: Own processing by Elcano Global Presence Index. 
Order of the V4 States within the EGPI - Science

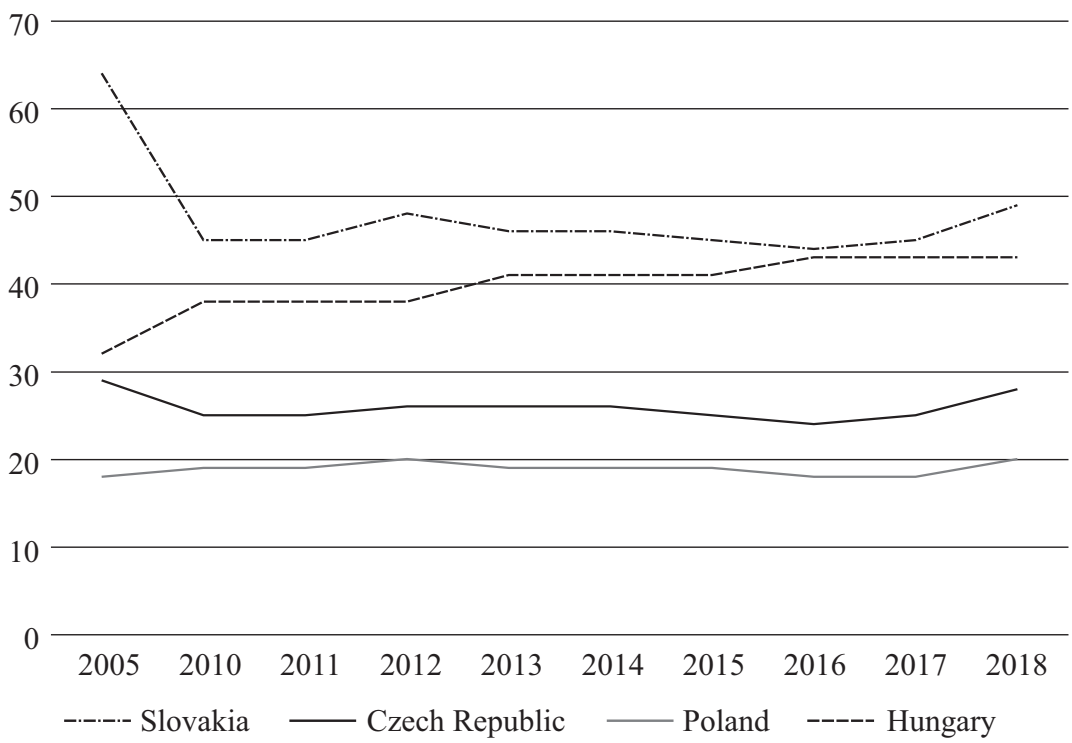

Source: Own processing by Elcano Global Presence Index.

In comparison with the V4 countries, the Slovak Republic has the lowest level of spending on research and development (R\&D). R\&D expenditure represents $0.88 \%$ of GDP (see Table 5), well below the EU average $(2.07 \%$ of GDP) and even less comparing to the EU target of 3\% of GDP to be spent on R\&D (Eurostat, 2019). While public investment has increased over the last decade, private sector investment is still one of the lowest in the EU.

Slovak investment in science and research has increased almost twice in relation to the GDP over the last decade. However, the European Commission drew attention to two issues in the country's assessment of the European Semester:

- public investment is too dependent on external resources, in particular European Structural and Investment Funds (Eurofunds), which calls into question the sustainability of public funding for science and research; and - although private investment has more than doubled (relative to GDP) over the last decade, it is still one of the lowest in the EU and, according to the Commission, too low to significantly boost innovation. As much as $39 \%$ of our R\&D investment relies on foreign sources of funding, in particular EU funds - accounting for $89 \%$ of the funding. 
In both cases, it is one of the highest shares in the EU. According to the European Commission, private investment in science and research appears to be too low to significantly increase innovation performance (Drapáková, Geist, 2019).

R\&D expenditure in\% of GDP

Table 5

\begin{tabular}{||l|c|c|c|c|c|c|c|c|c||}
\hline \hline $\begin{array}{c}\text { R\&D intensity (R\&D ex- } \\
\text { penditure in \% of GDP) }\end{array}$ & $\mathbf{2 0 0 5}$ & $\mathbf{2 0 1 0}$ & $\mathbf{2 0 1 1}$ & $\mathbf{2 0 1 2}$ & $\mathbf{2 0 1 3}$ & $\mathbf{2 0 1 4}$ & $\mathbf{2 0 1 5}$ & $\mathbf{2 0 1 6}$ & $\mathbf{2 0 1 7}$ \\
\hline Slovakia & 0.49 & 0.62 & 0.66 & 0.80 & 0.82 & 0.88 & 1.17 & 0.79 & 0.88 \\
\hline Czech Republic & 1.17 & 1.34 & 1.56 & 1.78 & 1.90 & 1.97 & 1.93 & 1.68 & 1.79 \\
\hline Poland & 0.56 & 0.72 & 0.75 & 0.88 & 0.87 & 0.94 & 1.00 & 0.96 & 1.03 \\
\hline Hungary & 0.92 & 1.14 & 1.19 & 1.26 & 1.39 & 1.35 & 1.36 & 1.20 & 1.35 \\
\hline EU Eurostat & 1.74 & 1.93 & 1.97 & 2.01 & 2.02 & 2.03 & 2.03 & 2.03 & 2.07 \\
\hline EU OECD & 1.66 & 1.83 & 1.86 & 1.91 & 1.92 & 1.95 & 1.96 & 1.94 & 1.97 \\
\hline
\end{tabular}

Source: Eurostat: Gross domestic expenditure on Research and Development, 2006-2016; OECD: Gross domestic spending on $R \& D$.

\section{R\&D intensity (R\&D expenditure in\% of GDP)}

$$
3.0
$$

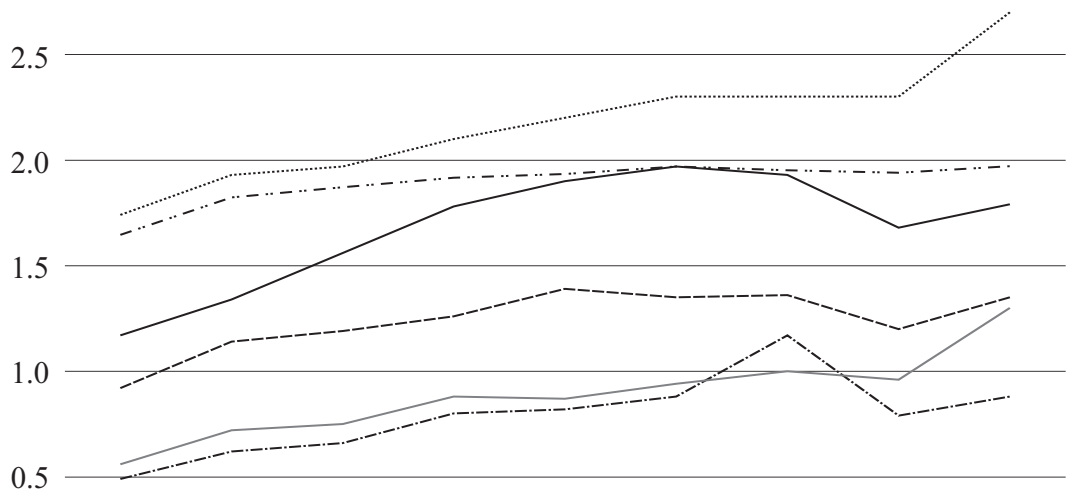

$$
\begin{aligned}
& \begin{array}{llllllllll}
0.0 & 2005 & 2010 & 2011 & 2012 & 2013 & 2014 & 2015 & 2016 & 2017
\end{array} \\
& \text { - Slovakia - Czech Republic — Poland ----- Hungary } \\
& \text { EU Eurostat } \quad \text {-..-.. EU OECD }
\end{aligned}
$$

Source: Own processing by Elcano Global Presence Index. 


\section{Education Index vs. Index of R\&D}

140
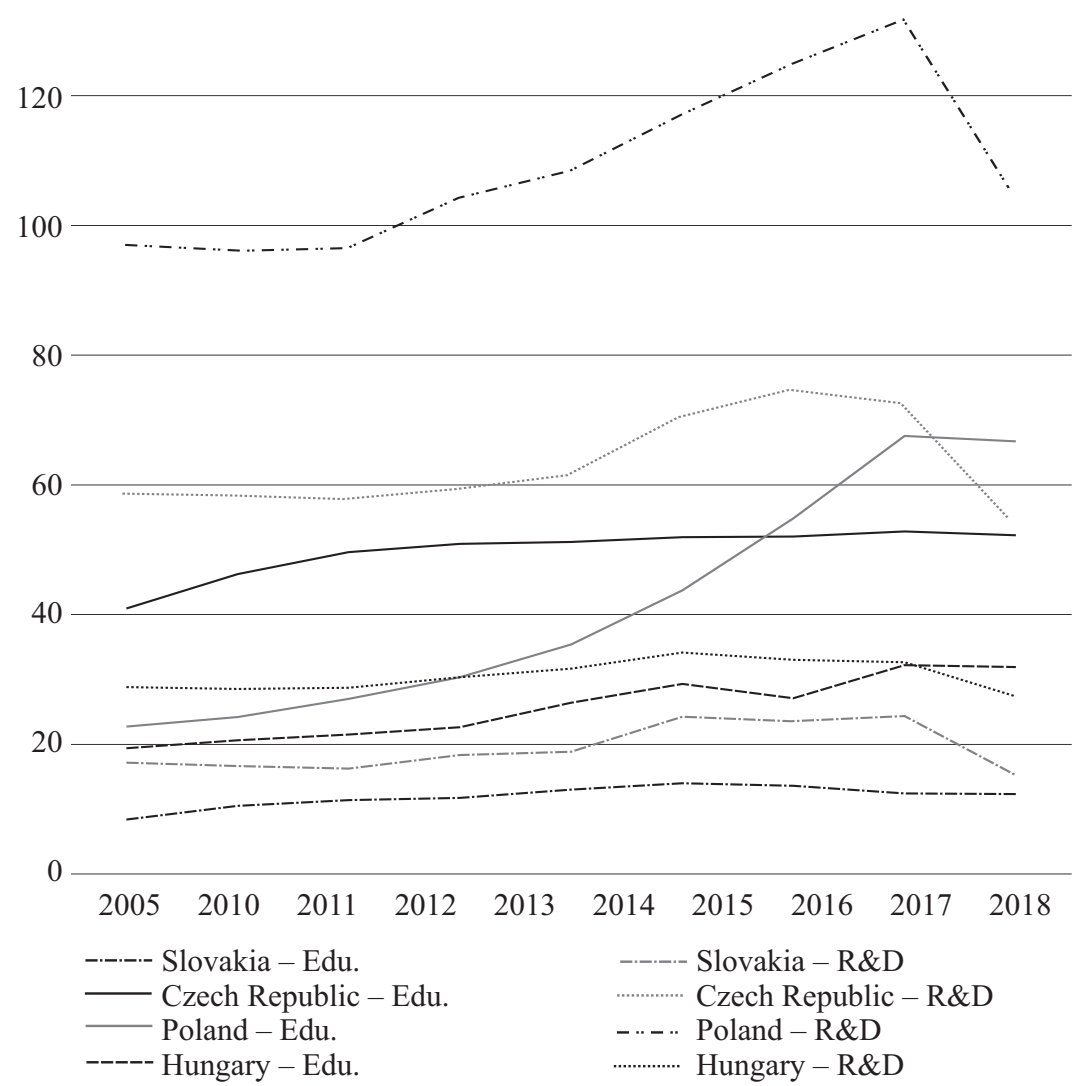

Source: Own processing by Elcano Global Presence Index.

The number of patents also reflects the performance of science. In 2017, 206 patent applications were filed - 183 by domestic and 23 by foreign entrepreneurs. This accounted for a $12 \%$ decrease compared to 2016. Of these, only seven were international applications. Most foreign applicants come from the Czech Republic (44\%) and Austria (ÚPV SR, 2018). Only 82 patents were granted in a given year (59 domestic, 23 foreign). In the statistics of the European Patent Office, Slovakia is ranked $24^{\text {th }}$ (in EU 28) with 41 patent applications (see Table 6) (EPO, 2017). In comparison with V4 countries, Slovakia is ranked last. Poland reached 
the best position, namely $14^{\text {th }}$ place among 469 Entries, Czech Republic $15^{\text {th }}$ with 205 applications and Hungary $20^{\text {th }}$ with 94 applications.

Table 6

European patent applications include direct European applications and international (PCT) applications

\begin{tabular}{|c|l|r|r|c||}
\hline Rank & \multicolumn{1}{|c|}{ State } & $\mathbf{2 0 1 7}$ & $\mathbf{2 0 1 6}$ & Difference \\
\hline 14. & Poland & 469 & 411 & $+14.1 \%$ \\
\hline 15. & Czech Republic & 205 & 190 & $+7.9 \%$ \\
\hline 20. & Hungary & 94 & 110 & $-14.5 \%$ \\
\hline 24. & Slovakia & 41 & 42 & $-2.4 \%$ \\
\hline
\end{tabular}

Source: EPO, 2017.

The number of patent applications is also stated in Table 7. The relatively low number of patent applications, as well as patents granted, shows the low creative activity and capacity of the country to benefit from new knowledge.

Table 7

Patent applications to the EPO, 2004 and 2014 (per million inhabitants)

\begin{tabular}{||l|l|l||}
\hline \multicolumn{1}{|c|}{ State } & \multicolumn{1}{c|}{$\mathbf{2 0 0 4}$} & \multicolumn{1}{c||}{$\mathbf{2 0 1 4}$} \\
\hline EU-28 & 113 & 112 \\
\hline Sweden & 250 & 349 \\
\hline Finland & 270 & 340 \\
\hline Germany & 280 & 256 \\
\hline Denmark & 206 & 244 \\
\hline Austria & 178 & 230 \\
\hline Netherlands & 226 & 205 \\
\hline France & 134 & 138 \\
\hline Belgium & 146 & 137 \\
\hline Luxembourg & 252 & 109 \\
\hline United Kingdom & 94 & 83 \\
\hline Italy & 80 & 70 \\
\hline Slovenia & 56 & 66 \\
\hline Ireland & 68 & 65 \\
\hline Spain & 29 & 33 \\
\hline
\end{tabular}

\begin{tabular}{|l|l|l||}
\hline \multicolumn{1}{|c|}{ State } & $\mathbf{2 0 0 4}$ & \multicolumn{1}{c|}{$\mathbf{2 0 1 4}$} \\
\hline Latvia* & 4 & 32 \\
\hline Czech Republic & 11 & 25 \\
\hline Hungary & 15 & 23 \\
\hline Lithuania & 3 & 17 \\
\hline Poland & 3 & 16 \\
\hline Portugal & 6 & 12 \\
\hline Greece & 6 & 11 \\
\hline Estonia & 6 & 10 \\
\hline Malta & 15 & 10 \\
\hline Slovakia & 4 & 9 \\
\hline Cyprus & 8 & 8 \\
\hline Bulgaria & 2 & 7 \\
\hline Romania & 1 & 5 \\
\hline Croatia & 7 & 3 \\
\hline
\end{tabular}

Note: * 2013 instead of 2014.

Source: Eurostat, https://ec.europa.eu/eurostat/statistics-explained/index.php/Archive:

Patent_statistics, October 2016. 
The Slovak Republic belongs to the category of small states. Although Joseph S. Nye refers to the theory of soft power using the example of the United States, the application of the theory is not limited. Every single state has soft power instruments, but not all of them use it fully and effectively. In comparison with other V4 countries, Slovakia is trying to benefit from its limited political, economic and strategic assets. They seek to overcome spatial constraints and thus open up wider opportunities to increase their impact abroad and on the international stage. States examined have long-term common experience in the previous geopolitical system. Although the Slovak Republic and the Czech Republic share common past as a single political unit, their current development and the nature of power or influence differ in many aspects.

We used the Elcano Global Presence Index as an assessment indicator of soft power to analyse not only national specificities but also compare the situation among the V4 countries. Two indicators were chosen as a reference framework for soft power assessment: education and science.

In the context of the Elcano Global Presence Index soft power assessment, the Slovak Republic lags significantly behind all V4 countries throughout the reporting period of 2010- 2018. In 2010-2014, or the beginning of the period under review, in contrast to other V4 countries, the Slovak Republic recorded the most significant drop in its position from $57^{\text {th }}$ in 2010 to $64^{\text {th }}$ in 2014 . Regarding both indicators, Slovakia lags significantly behind the V4 countries. In the case of education, Slovakia has recorded a significant drop in 2016-2018, by up to 7 places in the ranking. At the same time, Poland and Hungary also experienced a significant qualitative shift in its position.

The situation in science and research, in comparison with education, is not so significantly different with larger inter-state differences. The situation of Slovakia is actually the worst among the V4 countries. It should be noted that in the period under review (2016-2018), the Slovak Republic was worst off by the largest spread of 5 places. However, in the longer term, the situation in science and research is much more balanced than in the case of education.

Looking at a longer term over the reporting period, we may see different priorities within the V4 countries in terms of soft power (see Table 8). In recent years, in the Slovak Republic, the priority was tourism 


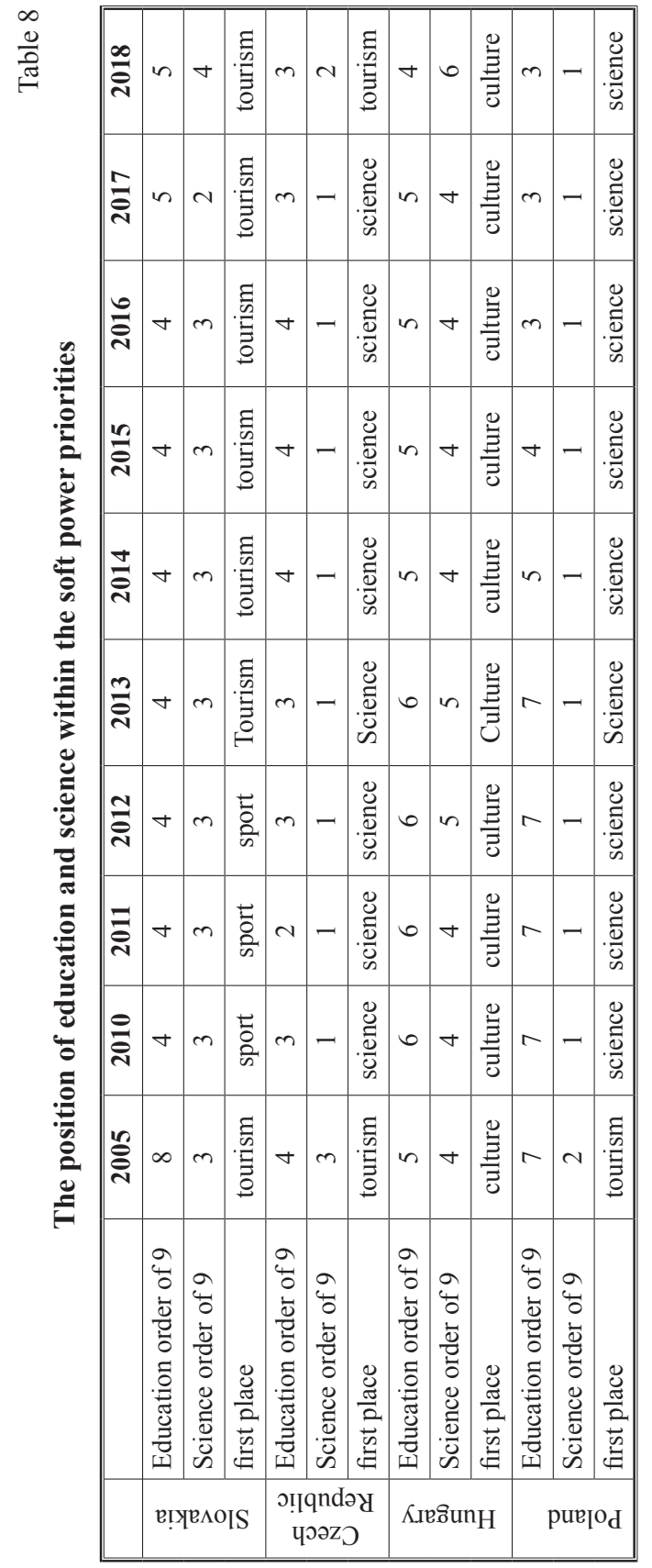


and sports, whereas in Hungary, it was culture throughout the period under review. On the contrary, both the Czech Republic and Poland put major emphasis in soft power and support for science, with the exception of 2018 in the Czech Republic, when tourism prevailed. Compared to other 9 indicators, education maintains its $3^{\text {rd }}-4^{\text {th }}$ position in the Czech Republic. In Poland, in the period under review, education recorded a significant qualitative shift from $7^{\text {th }}$ place in 2013 to the $3^{\text {rd }}$ place this year. This shift, as well as the first place in science, points to clear priorities of Poland in soft power and support for science and education. The same applies to the Czech Republic.

The situation is different in Slovakia and Hungary. In Slovakia, the position of both science and education has deteriorated considerably and at present education is ranked $5^{\text {th }}$ and science $4^{\text {th }}$, which is the worst ranking regarding both indicators since 2010. In Hungary, the situation is similar, science is ranked $6^{\text {th }}$ which is the worst position of all V4 countries. This "tabular slump" may also reflect the current political development in Hungary and the attitude of the Hungarian government towards academics.

It should be emphasized that the education system is one of the vital spheres and its deterioration leads to the degradation of the whole country. Also, the effectiveness of higher education as a soft power tool can only be evaluated in a longer period.

\section{Conclusion}

The importance of an environment which is conducive to R\&D in the current technological development period is a prerequisite for the growth of the influence and attractiveness of the image of a state abroad. In comparison with all other V4 countries, the Slovak Republic has very unfavourable conditions for science and research, especially in terms of support for science and research expressed as a percentage of GDP. Despite the fact that none of the countries is below the EU average in $R \& D$ expenditure, the position of the Slovak Republic has been the worst in the long term compared to the V4 countries. Until 2015, there was a relatively positive development in support for R\&D in the long term, which still was the lowest among all other countries. After 2015, Slovakia recorded a significant decrease in R\&D expenditure. Currently, $\mathrm{R} \& \mathrm{D}$ expenditure is well below $1 \%$ of GDP. The Czech Republic has 
the largest expenditure, although the country also witnessed a drop in $R \& D$ expenditure after 2015 . It is the R\&D expenditure in terms of GDP percentage that shows a direct correlation with the importance of science and education in the framework of soft power. The only exception to this is Hungary, which spends approximately the same percentage of GDP on science and research, but within its soft power priorities, Poland spends four times the level of the science index.

In Slovakia, science (R\&D) has been underfunded for a long time. This results in stagnation. Such a situation is associated with the outflow of Slovak students and graduates abroad, whereby the state is losing its qualified workforce. Support for science and research, together with support for education and higher education, would help to boost innovation and sustainable development, thereby raising the standard of living of the population. With a higher standard of living, the soft power potential as well as the attractiveness of the country may also improve. Similarly, a higher level of science and research in the country would make the country more attractive for foreign investors or businesses manufacturing products of higher added value, the same applies to researchers, scientists and experts in various fields.

There is no significant increase in R\&D funding. This is due to the slowdown of the progress and, in recent years, mainly to the brain drain of Slovak intelligence going abroad, which further deteriorates the attractiveness of education and hampers the functioning of science.

Educated people are not able to convert their education and financial resources into a potential profit - both regarding the economy and increased awareness of the country and its attractiveness. The key to boosting creativity of the Slovaks is to increase the support for scientific research through making funding available and creating qualified jobs for scientists, researchers and innovators.

\section{Bibliography}

Drapáková D., Geist R. (2019), Investície do výskumu závisia od eurofondov, EURACTIV.sk, 17. sep. 2019 [cit. 2019.09.19], https://euractiv.sk/section/ekonomika-a-euro/infographic/investicie-do-vyskumu-zavisia-od-eurofondov/.

EPO (2017), European patent applications. In EPO Statistics and indicators, [cit. 2019.09.14], https://www.epo.org/about-us/annual-reports-statistics/annualreport/2017/statistics/patent-applications.html\#tab2. 
EUROSTAT (2019), Research and development expenditure (\% of GDP) 2017, in: Science, technology and innovation - Overview [cit. 2019.07.17], https:// ec.europa.eu/eurostat/cache/BubbleChart/?lg=en\#tableCode=rd_e_gerdtot.

EUROSTAT (2016), Archive: Patent statistics, October 2016 [cit. 2019.09.14], https://ec.europa.eu/eurostat/statistics-explained/index.php/Archive:Patent statistics.

OECD: Gross domestic spending on $R \& D$, https://data.oecd.org/rd/gross-domesticspending-on-r-d.htm.

Úrad Priemyselného Vlastníctva SR, (2018), Výročná správa 2017, Úrad priemyselného vlastníctva SR, Banská Bystrica, $52 \mathrm{~s}$.

\section{Edukacja i nauka jako miękkie narzędzie w Słowacji i krajach V4}

\section{Streszczenie}

Edukacja była już ważnym źródłem władzy i statusu w średniowieczu, w czasach pierwszych uniwersytetów. W dzisiejszych czasach edukacja, wraz z jakością i poziomem nauki, jest wykorzystywana jako środek promowania narodowych interesów za granicą, a także wywierania wpływu na lokalne elity, a czasem nawet na większą populację. Wysoki poziom edukacji wysokiej jakości jest jednym z czynników budujących relacje władzy międzypaństwowej. Rola edukacji w międzynarodowym prestiżu i pozycja krajów znacznie wzrosła w ostatnich latach, głównie z powodu poważnych zmian w światowej gospodarce i odpowiedniego przesunięcia wartości, które stały się ważne w procesach modernizacji społeczeństwa. Edukacja staje się zatem coraz ważniejsza, zwłaszcza wraz z rosnącym znaczeniem wiedzy w zglobalizowanym świecie. Edukacja staje się zatem coraz ważniejszym czynnikiem w stosunkach międzynarodowych i przekłada się na miękką siłę kraju.

Słowa kluczowe: edukacja, nauka, uniwersytety, patenty 